\title{
Algae as a biorefinery: generic applicable resonance of bio-ecological engineering in exploring possibilities for desert landscape
}

\author{
Dipankar Saha $^{1^{*}}$, M. S. Raghuvanshi ${ }^{2}$ and Anurag Saxena ${ }^{1}$ \\ ${ }^{1}$ Regional Research Station, ICAR-Central Arid Zone Research Institute, Ministry of \\ Agriculture, Government of India (An ISO 9001:2015 Certified Institute), Stakna, Hemis \\ Road, Ladakh-194 201, India \\ ${ }^{2}$ Division of Land Use Planning, ICAR-National Bureau of Soil Survey and Land Use \\ Planning, Amravati Road, Nagpur-440 033, Maharashtra, India
}

*Corresponding author

\section{A B S T R A C T}

\section{Keywords}

Algae, bioenergy, eco-engineering, biofuel,

bioproducts, sustainability, energy management, desert landscape

Article Info

Accepted:

25 February 2020

Available Online:

10 March 2020

\begin{abstract}
Algae and more so microalgae are already occupied a place in everyone's life and also expected to be a major part of global socio-marketing dynamics as these living wonders are rich in proteins, carbohydrates, and lipoproteins of high density etc. Apart from its multiple usage likely that as bio-fertilizers; source of pharmaceuticals, nutraceuticals and other bio-based products; as livestock feed; in treating wastewater for better environmental management these organisms are also a renewable power house for bioenergy as it is a viable sources of biofuel which has already been experimented in different parts of the globe and also became the priority for the corporate sectors to research, innovate and commercialize as one of the best way in managing energy crisis with renewable resources like this including the government to adopt and implement. This paper is an effort to have a generic insight into these aspects and issues and the potential of algae as a concept of "biorefinery" with a little bit of categorical view on its basic and applicable domain with some special reference to the potential of few desert landscape of the world and its possible experimentations in Indian context.
\end{abstract}

\section{Introduction}

During $20^{\text {th }}$ century, the state of yield improvement in agriculture in a steady state has certainly increased food security and limited agricultural and land-use change (LUC), greenhouse gas emissions, however, future yield increase may not be that enough to achieve climate goals and meeting food demand. It is understandable that the use of terrestrial crops as source for biofuels will exert quantum pressure on food production and we could perhaps exposed to increased LUC and water use. In this context algae have been rightfully can be proposed as an alternative source of biofuel due to its higher productivity than that of terrestrial crops.

Algae being an unicellular to multi-cellular organisms with varied morphological attributes occurring in a wide range of habitats and its distribution are there in all 
types of land and water system and are extremely adaptable to extreme environmental conditions. In India, as per recent estimates, approximately there are 7310 species of algae occurs belonging to 855 genera and 252 families. Algae being the source of many products of commerce (Table 1) having high trade values (Table 2) like pharmaceuticals, nutraceuticals, chemicals, fertilizers, bio-oils, biofules etc. are having huge importance not only as a primary producers but also as a source of third generation biofuel being the rich source of fatty acids as reported in Botryococcus braunii (Fig.1, Fig.2 and Table 3) when there is the global projections of future energy crisis and thus a world wide effort in search for the sustainable alternative is in place.

Algal farming is being ignited due to the global crisis on food and energy and for making algal biodiesel and biofuels from land unsuitable for agriculture is in the fore front due to characteristic features of high flash point, bio-degradable nature and having minimal impact on fresh water resources; commercial productive potential from saline and wastewater etc.

In 1942 Harder and Von Witsch in 1942 were the first to suggest that algae can be grown as a lipid source for food or fuel and after second World War, research and development started in the US, Germany, Japan, England and Israel etc. on technicalities cum bioengineering of culturing systems for bulk industrial production with special reference to genus Chlorella and in this directions Aach in 1952 further expressed that Chlorella pyrenoidosa placed under nitrogen starvation leads to accumulate lipids to 70 per cent of its dry weight. Reports also suggests that Nostoc species, a common microalga was used for surviving drought 2,000 years back by the Chinese people, however, of late the application of innovative bioresource technologies on algae started emerging as cited by Priyadarshani and Rath in 2012. Algae requires less amount of water and nutrients to grow rapidly in comparison to land plants. Hannon et al in 2010 and Ercin et al in 2012 inferred that $1 \mathrm{~kg}$ of algal biomass required 333 liters of water whereas $1 \mathrm{~kg}$ of soy requires 2,204 liters of water. Ayyappan et al in 1991 have inferred that Spirulina species is a unique feed supplement for fish as a result of long-term experimentation on various types of Indian major carps.

In this context it is pertinent to elucidate the concept of "biorefinery" in terms of algae to convert this biomass into value added products and energy in a homoeostatic way which is being nurtured and propagated by countries like United States, United Kingdom, China, Canada, Spain, Japan etc. (Table 4) as explained by González-Delgado and Kafarov (2011) and very little in India also. The selection of raw materials and the technologies cum processes involved are two pillars of success for an effective and efficient biorefinery and in this direction algae are primarily been considered as one of the best bioresources available in the green planet. These organisms unlikely that of terrestrial plants with which the degradation processes are much easier to produce multiple valueadded products and residual biomass valorization towards sources of biofuel (Fig. $3)$.

Therefore, the basic concept of a biorefinery framework should encompasses selection of organisms and strains used suitable for the climate, productivity, biochemical composition and the possibility of extracting value-added products etc. both for open race ways and for the industrial level production system through bioreactors etc. as opined by various scholars like Hariskos and Posten in 2014. 
Table.1 Microalgae species for extraction of high-value compounds and its application (few examples)

\begin{tabular}{|l|l|l|}
\hline Microalgal species & High value products & Broad areas of application \\
\hline Chlorella vulgaris & Biomass, pigments & Health food, food supplement \\
\hline Coccomyxa acidophila & Lutein, $\beta$-carotene & Pharmaceuticals, nutrition \\
\hline $\begin{array}{l}\text { Coelastrella striolata } \text { var. } \\
\text { multistriata }\end{array}$ & $\begin{array}{l}\text { Canthazanthin, astaxanthin, } \\
\beta \text {-carotene }\end{array}$ & Pharmaceuticals, nutrition, cosmetics \\
\hline Crypthecodinium conhi & Docosahexaenoic acid & Pharmaceuticals, nutrition \\
\hline Diacronema vlkianum & Fatty acids & Pharmaceuticals, nutrition \\
\hline Dunaliella salina & Carotenoids, $\beta$-carotene & Health food, food supplement, feed \\
\hline Galdiera suphuraria & Phycocyanin & Pharmaceuticals, nutrition \\
\hline Haematococcus pluvialis & $\begin{array}{l}\text { Carotenoids, astaxanthin, } \\
\text { cantaxanthin, lutein }\end{array}$ & $\begin{array}{l}\text { Health food, pharmaceuticals, feed } \\
\text { additives }\end{array}$ \\
\hline Isochrysis galbana & $\begin{array}{l}\text { Fatty acids, carotenoids, } \\
\text { fucoxanthin }\end{array}$ & $\begin{array}{l}\text { Pharmaceuticals, nutrition, cosmetics, } \\
\text { animals nutrition }\end{array}$ \\
\hline Lyngbya majuscule & Immune modulators & Pharmaceuticals, nutrition \\
\hline Muriellopsis sp. & Lutein & Pharmaceuticals, nutrition \\
\hline Nannochloropsis gaditana & Eicosapentaenoic acid & Pharmaceuticals, nutrition \\
\hline Odontella aurita & Fatty acids & Pharmaceuticals, cosmetics, baby food \\
\hline Parietochloris incise & Arachidonic acid & Nutritional supplement \\
\hline Phaedactylum tricomutum & $\begin{array}{l}\text { Lipids, eicosapentaenoic } \\
\text { acid, fatty acids }\end{array}$ & Nutrition, fuel production \\
\hline Porphyridium cruentum & $\begin{array}{l}\text { Arachidonic acid, } \\
\text { polysaccharides }\end{array}$ & Pharmaceuticals, cosmetics, nutrition \\
\hline Scenedesmus almeriensis & Lutein, $\beta$-carotene & Pharmaceuticals, nutrition, cosmetics \\
\hline Schizochytrium sp. & Docosahexaenoic acid & Pharmaceuticals, nutrition \\
\hline Spirulina platensis & $\begin{array}{l}\text { Phycocyanin, } \gamma \text {-Linolenic } \\
\text { acid, biomass protein }\end{array}$ & Health food, cosmetics \\
\hline Ulkenia spp. & Docosahexaenoic acid & Pharmaceuticals, nutrition \\
\hline
\end{tabular}

Table.2 High value compounds from algae and its market value

\begin{tabular}{|c|c|c|}
\hline Products & Price in $€$ and INR & References \\
\hline Phycobiliproteins & $€ 11-50 \mathrm{mg}^{-1}=$ INR $896.5-4,075 \mathrm{mg}^{-1}$ & Brennan and Owende (2010) \\
\hline \multirow[t]{2}{*}{ B-Phycoerythrin } & $€ 0.036 \mathrm{mg}^{-1}=2.934 \mathrm{INR} \mathrm{mg}^{-1}$ & Markon and Nerantzis (2013) \\
\hline & $€ 105 \mathrm{mg}^{-1}=\mathrm{INR} 8558 \mathrm{mg}^{-1}$ & Spolaore et al (2006) \\
\hline C-Phycocyanin & $€ 360-72460 \mathrm{~kg}^{-1}=$ INR $29340-59,05,490 \mathrm{~kg}^{-1}$ & Borowitzka (2013) \\
\hline \multirow[t]{2}{*}{ B-Carotene } & $€ 215-2150 \mathrm{~kg}^{-1}=$ INR $17,523-1,75,225 \mathrm{~kg}^{-1}$ & Brennan and Owende (2010) \\
\hline & $€ 218-510 \mathrm{~kg}^{-1}=$ INR $17,767-41,565 \mathrm{~kg}^{-1}$ & Markon and Nerantzis (2013) \\
\hline \multirow[t]{2}{*}{ Astaxanthin } & $€ 7150 \mathrm{~kg}^{-1}=$ INR $5,82,725 \mathrm{~kg}^{-1}$ & Brennan and Owende (2010) \\
\hline & $€ 1450-5075 \mathrm{~kg}^{-1}=$ INR $1,18,175-4,13,613 \mathrm{~kg}^{-1}$ & Markon and Nerantzis (2013) \\
\hline \multirow[t]{3}{*}{ DHA Oil/Omega-3 } & $€ 0.043 \mathrm{~kg}^{-1}=$ INR $3.5045 \mathrm{~kg}^{-1}$ & Brennan and Owende (2010) \\
\hline & $€ 0.63-2.78 \mathrm{~kg}^{-1}=$ INR $51.345-226.57 \mathrm{~kg}^{-1}$ & Markon and Nerantzis (2013) \\
\hline & $€ 78-116 \mathrm{~kg}^{-1}=\mathrm{INR} 6357-9454 \mathrm{~kg}^{-1}$ & Borowitzka (2013) \\
\hline
\end{tabular}

Converting 1 EURO=81.50 INR 
Table.3 Botryococcus braunii and its fatty acids composition (Source: Ramaraj et al, 2016)

\begin{tabular}{|l|c|}
\hline \multicolumn{1}{|c|}{ Fatty acid } & \% \\
\hline Cyclohexane (C 12 ) & $2.63 \pm 0.01$ \\
\hline Lauric acid (C 12:0) & $0.41 \pm 0.34$ \\
\hline Myristic acid (C 14:0) & $1.38 \pm 0.29$ \\
\hline Pentadecanoic acid (C 15:0) & $0.84 \pm 0.10$ \\
\hline Palmitic acid (C 16:0) & $19.32 \pm 0.08$ \\
\hline Palmitelaidic acid (C 16:1) & $11.67 \pm 0.80$ \\
\hline Heptadecane (C 17) & $1.44 \pm 0.30$ \\
\hline Margaric acid (17:0) & $0.60 \pm 0.12$ \\
\hline Stearic acid (C 18:0) & $06.10 \pm 0.13$ \\
\hline Oleic acid (C 18:1) & $34.74 \pm 0.07$ \\
\hline Elaidic acid (9-18:1) & $0.56 \pm 0.06$ \\
\hline Linoleic acid (18:2) & $05.56 \pm 0.07$ \\
\hline Linolenic acid (C18:3) & $06.32 \pm 0.11$ \\
\hline Homo-y- linolenic acid (20:3) & $00.36 \pm 0.11$ \\
\hline Eicosatrienoic acid(20:4) & $01.24 \pm 0.05$ \\
\hline Docosanoic acid (C22:0) & $03.09 \pm 0.09$ \\
\hline Erucic acid (C22:1) & $05.05 \pm 0.01$ \\
\hline Lignoceric acid (24:0) & $01.87 \pm 0.09$ \\
\hline 2-Pentadecanone,6,10,14-trimethyl & $00.92 \pm 0.31$ \\
\hline 6-Octen-1-ol, 3,7-dimethyl acetate & $00.31 \pm 1.73$ \\
\hline 1,3-Cyclohexanediamine & $00.17 \pm 0.55$ \\
\hline (1R,4S)-1,7,7-Trimethylbicycloheptan-2-yl3- & $00.79 \pm 0.63$ \\
\hline hlorobenzoate & $00.25 \pm 0.36$ \\
\hline 2-Methylthio-5-nitro anisole & $00.22 \pm 0.28$ \\
\hline Ethyl4,8,12-trimethyl-tridecanoat & \\
\hline
\end{tabular}

Table.4 Industrial houses investment in microalgae cultivation around the world (few examples)

\begin{tabular}{|l|c|l|c|}
\hline Algal species & Cultivation Type & Industry/Product & Country \\
\hline Dunaliella & Closed & $\beta$-carotene & Israel \\
\hline Dunaliella & Open & $\beta$-carotene & Australia \\
\hline Haematococcus & Open & Astaxanthin & Hsrael \\
\hline Haematococcus/Spirulina & Open & (Astaxanthin/Dietary supplement) & Sweden \\
\hline Haematococcus & Closed & Astaxanthin & USA (California) \\
\hline Spirulina & Open & Dietary supplement & Taiwan \\
\hline Spirulina/Chlorella & Open & Dietary supplement & Germany \\
\hline Chlorella & Closed & Dietary supplement & USA (Florida) \\
\hline Cyanobacteria & Closed & Ethanol, diesel, jet fuel & USA (New Mexico) \\
\hline Unknown & Closed & Jet fuel & Brazil \\
\hline Unknown & Closed & Biodiesel & USA (Florida) \\
\hline Unknown & Open & Wastewater treatment & New Zealand \\
\hline Unknown & Open & Wastewater treatment \\
\hline
\end{tabular}




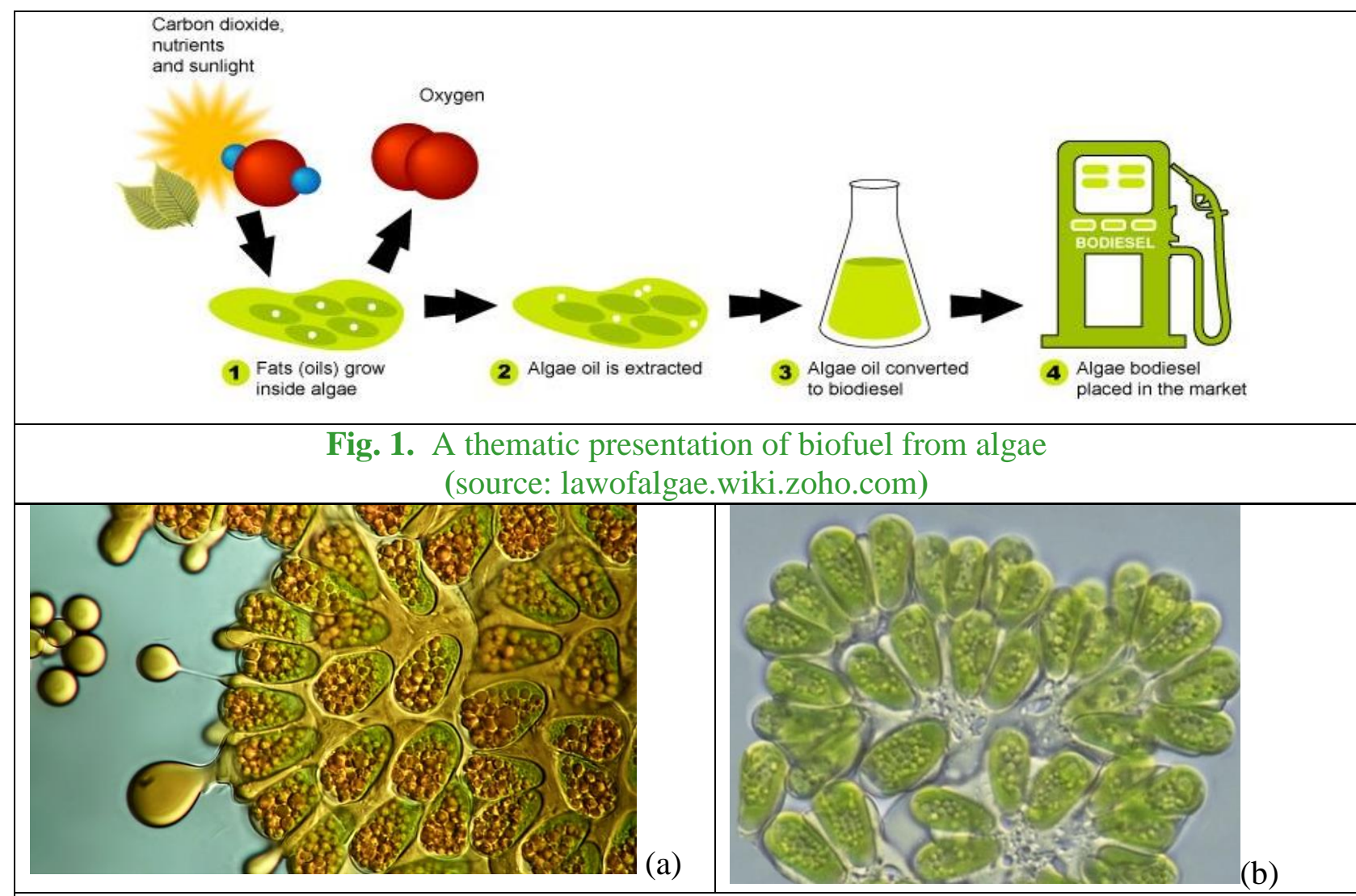

Fig.2. Botryococcus braunii- a potential algae for biofuel (a) oils are seen being exuded from algae (Source: $c f b . u n h . e d u)$ and (b) colony seen under microscope.

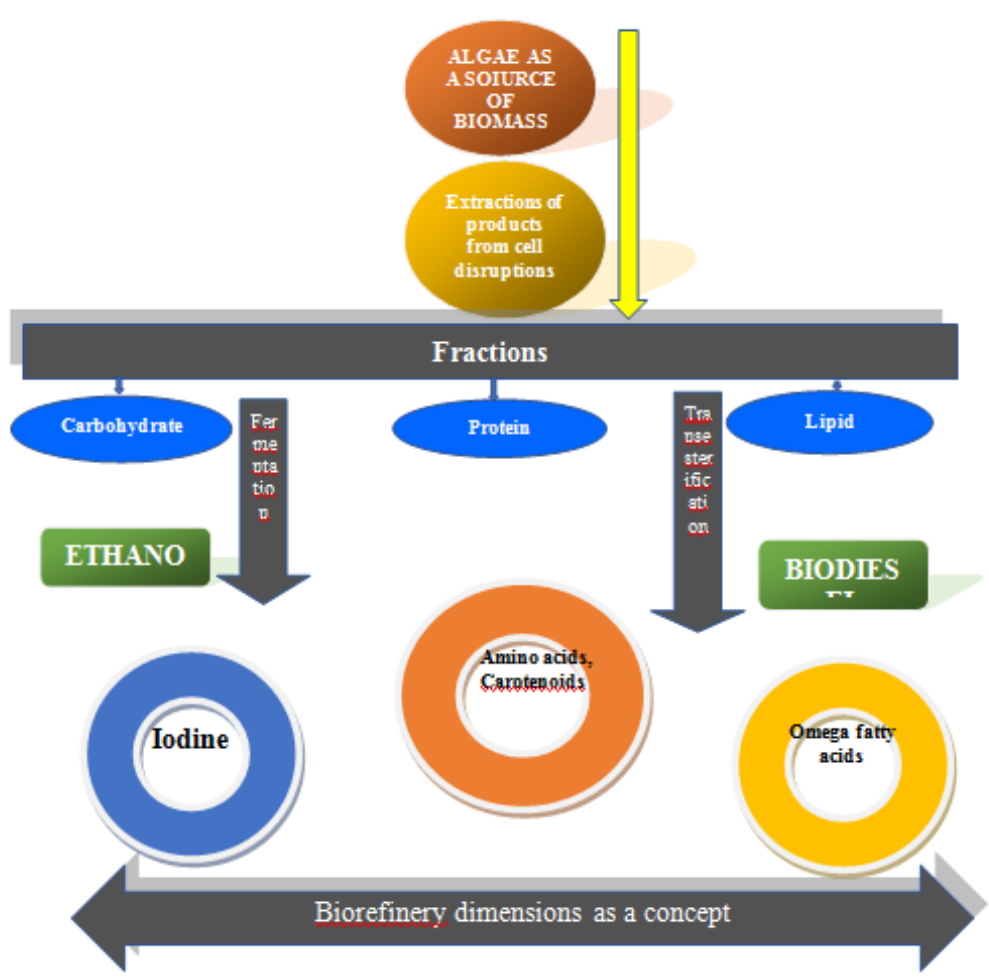

Fig. 3. Schematic representation of algal biorefinery (adapted and modified from Chew KW et al, 2017). 
The concept of biofuels is comparatively new concept for the civilization. Utilization of biological material for producing energy dates far back in the history of mankind but recent decades only started observing the effort in exploiting them as a greater scale substitute as rightly opined by El Bassam in 1998. If we also correctly remember the words of Rudolf Diesel as expressed in 1912 and 1913 as "The diesel engine was constructed for using mineral oil, and was then worked on vegetable oil without any alterations being made", thus we can very easily cogitate the inner narratives, i.e; around 1900, even when the first diesel engine has been tested, that was with an aim to see if it could function with the help of a non-mineral alternative. It is a wondering fact that civilization have not remembered the very significant above analogy made by Rudolf Diesel almost a century back and thus failed to concentrate on plant resources during this by gone century for powering machines and/or engines. This first generation of biofuels faced the sharp criticism and failed to stand the questions, whether it is sustainable or not, as this term signifies and being the very basis of the Brundtland report of 1987 "Our Common Future". As Ajanovic during 2010 raised the ethically debatable issues as "food for fuel" world started discussing about social implications of conversion of arable land to land for energy harvest and utilization.

\section{Materials and Methods}

This conceptual study was conceived and undertaken during year 2018-19 and 2019-20 with the objective to have a synthesis on research and developmental applications in the desert landscape (both hot and cold arid ecosystem) of the country for alternative bioresources utilization to ensure energy security through green energy harvesting as a part of sustainable natural resources utilization and environmental management.
In a place like cold desert where precipitation is on an average side, the daily range from 0.5 to $1.5 \mathrm{~mm} /$ day. These conditions define the climate of the Leh region as cold and arid (dry) by Chevuturi et al in 2018. It has a cold desert climate (Köppen climate classification BWk) with long, harsh winters from October to early March, with the temperature range from $-28{ }^{\circ} \mathrm{C}$ in winter to $33{ }^{\circ} \mathrm{C}$ in summer. This region receives occasional snowfall during winter. Region experiences mean annual precipitation of $80-300 \mathrm{~mm}$, which is scanty and negligible in the thirsty laps of mountains. While hot desert, the temperature ranges from 35 degree Celsius to 40 degree Celsius. Around 90\% rains occur during this period. The Post monsoon season lasts from October to November. The temperature during this season ranges from 33 degree Celsius to 38 degree Celsius. Majority of the soils in Ladakh region are sandy to sandy loam in texture and medium to medium-high (e"0.75\%) in organic matter with poor water holding capacity. The $\mathrm{pH}$ ranged from 5.65 to 10.12 in Leh and $\mathrm{pH}$ of Kargil varied from 6.57-9.47, indicating alkalinity in nature. Electric conductivity ranged from 0.05-1.56 $\mathrm{dS} / \mathrm{m}$ in Leh district and 0.08-1.55 $\mathrm{dS} / \mathrm{m}$ in Kargil respectively. More than $90 \%$ soils are low in available nitrogen and phosphorus but high in potassium with availability of the potassium depending upon the other parameters of the soil.

A total of 32 million ha is hot arid situated in Rajasthan and Gujarat and the remaining 7 million ha is a cold arid zone situated in the Ladhakh area of Jammu and Kashmir and the Lahul Spiti area of Himachal Pradesh as mentioned by Behera and France in 2016. The cold arid zone records less than 8 hours per day while the hot arid zone records 9 to 10 hours per day the highest being over Rajasthan, Gujarat and Maharashtra regions 
(Reddy). In Cold arid region, Shah in 2012 revealed the global solar radiation is as high as $6-7 \mathrm{Kwh} / \mathrm{mm}$ which is among the highest in the world. These climatic features are of significant importance in conceptualizing and exploring the possibility of algal farming commercialization as sustainable potential sources of green energy as an radical approach to mitigate the climate change impact which is having its already inferred foot print in the desert ecosystem of India.

This review study is a preliminary effort to put a brief highlight on the potentials of few remarkable algal species out of thousands about their long researched applications for varied purposes with some specific references on studies covered likely (i) the microalgae species for extraction of high-value compounds and its application; (ii) high value compounds from algae and its market value; (iii) an example on unique species of Botryococcus braunii and its fatty acids composition and reflections on global level industrial houses researches in microalgae cultivations and to reflect it's potential of rural farming to industrial level productions for any ecological regions and more particularly so for desert landscape having huge quantum of non-arable lands coupled with critical catalytic biophysical attributes like temperature and light radiation.

\section{Results and Discussion}

Temperature and light radiation are two important criteria playing an pivotal role in algae based biotechnology instead of its culture management practices as opined by Allen in 2018. Bahadar and Khan in 2013 enlisted few important biofuel microalgal species with respect to their high growth potential and lipid contents. These are Botryococcus braunii, Chlamydomonas reinhardtii, Chlorella emersonii, Chlorella minutissima, Chlorella protothecoides,
Chlorella. vulgaris, Chlorococcum spp., Crypthecodinium cohnii, Dunaliella salina, Dunaliella tertiolecta, Microcystis aeruginosa, Nannochloropis spp., Phaeodactylum tricornutum, Scenedesmus obliquus, Schizochytrium spp., Spirulina maxima, Spirulina platensis etc. There are standard methodological procedures of lipid extractions and transesterification exist but Razon and Tan 2011 emphasized that better and cost effective technology is of great necessity to ensure microalgal biodiesel systems viable from an energy harvest perspective. This is possible within a larger framework of "biorefinery concept" as also mentioned by Razon and Tan in 2011 and Roberts et al in 2013 wherein they stressed on developing a biorefinery system coupling with waste water treatment network, philosophy of carbon capture alongside a storage system.

\section{Wastewater treatment and algal farming}

In treating waste water, its nutrient load can eventually be utilized as a source for algal growth. This is a unique model of phytoremediation by which the overloaded nutrients will not be able to reach rivers and lakes downstream and thereby can reduce the possibility of reducing the appearance of toxic microbial and algal bloom. Wastewater has the ability to supply large quantity of nonpotable water to algal farms and doesn't confront the supply for municipal and crop farming needs. Algal farming in wastewater is not only remediating the water but also reduces the extremely high cost of wastewater treatment. Allen in 2018 opined that it's high time to compare the wastewater treatment plants along side land available for algal productions and this understanding will be an extremely important control for us to find out the effectivity of a system which coupled the wastewater-algae system. Even Pienkos and Darzins in 2009 also expressed that better 
integration of microalgal cultivation and wastewater treatment processes always seek an innovative challenge basically due to fundamental interactive matrix between biology, ecology and technology and here is the relevance of "bio-ecological engineering" principles lie. Lau et al in 1995 and Bhatnagar et al in 2010 reported that a significant proportion of municipal waste treatment has already been implemented by uncontrollable naturally occurring algae like Cholerella and Scenedesmus species.

\section{Desert landscape-a potential ecosystem in place}

One of the greatest advantages of algal farming is that we need not to use arable land masses or the forested areas but can easily be compromised by using waste water systems, sewages and also at desert landscape as it is being experienced by various research groups at various countries having the desert landscape having the plenty of sunshine and little access to water which is unusable for drinking i.e; saline one. The wastelands or marginally arable lands of this landscape can easily be used for harvesting this green energy and it reflects a unique proposition to the debate regarding food prices and agricultural land use. But before taking this research to develop a venture as a feasible one, one need to select the right strain and growing methods which will ensure the evaporation should not affect the growth. If we have a close analytical look into a news coverage in "The National" of Abu Dhabi that "algae from United Arab Emirates (UAE) desert salt flats could be biofuel for the future" and it is a very simple derivable logic for every one of us keeping in view their land use pattern and the potential of few particular land types for the purpose of green energy harvest due some of the pertinent points which are applicable to any nations having huge areas and different types of desert landscape like India. The point of relevance are (i) algae being one of the many forms of plant life can be harvested as an alternative renewable energy source to drive escalating economies without adding further to global warming, (ii) to make biofuel really sustainable, algae is not used to take away other important resources and consequently desert algae is of great appeal, (iii) algae that grows and sustain in harsh desert environment necessarily not taking away farm land and since time immemorial manages to thrive in a landscape or in any niches of that where food and other crops cannot grow, (iv) desert algae is usually tolerant to salt water and it lives in highly saline salt flats which reflects a reasoning that it doesn't require freshwater to grow, a resources so precious and gradually becoming rare, (v) presence of thousands of local algal strains are available which are best suited for their cultivation and energy extraction etc. and all these features are critically relevant for any desert landscape and now it's the time to reinvent those dimensions for their future applicability as a source of green energy and a resilient local-regional and national economy. Israel and many other countries are also a leading and innovative example in this direction.

\section{Bio-ecological Engineering in Harvesting Wonder Green Energy}

Before peeping into the world of biofuels in general and recommending the utilization of algae as an alternative, the sustainable potential of algae as a third-generation biofuel producers: algal cells (commonly called "oilgae" in the canvas of biofuel world) need to be discussed and analysed. Many researchers during 2008-2010 inferred that algae is having the potential to produce up to 30 times more fuel per hectare than generally used crop plants for bioenergy like soybean and cotton. Very specifically microalgae are having the ability to grow in any regions, 
landscape, habitat, climatic and altitudinal gradients. In addition, these living organisms can come up very luxuriously in waste water with a supplementary benefit of its remediation capability of these waters which normally are being loaded with $\mathrm{CO}_{2}$ or even NO. On the other side, we need to visualize that algal technology (Fig.4 a, b) is still in its growing stage and at the global level the scientists (both from public, private and corporate world) are now trying to figure it out worldwide how to handle and use them. The selection of high yielding strains, media and culture techniques optimization, energy balances drawing for algal growth in natural and artificial light for algal growth, commercial plants designing in parallels with maintaining of sustenance and managing and maintaining associated ecological issues and concerns are also being considered by these scholars.

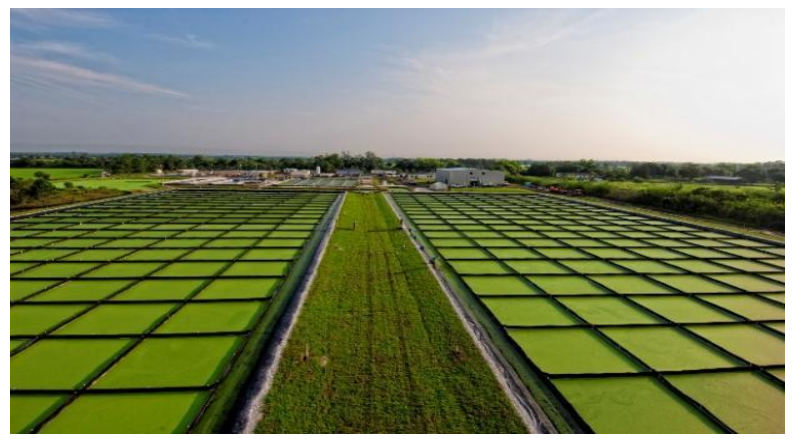

(a)

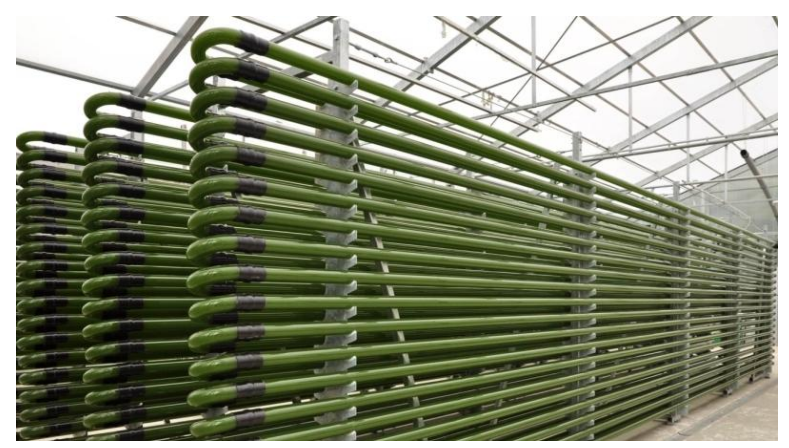

(b)

Fig. 4.(a) PetroAlgae-a company is claiming that it has found a cheap way to convert algae into fuel (photo source: PetroAlgae) and (b) Biofuel production from algae (source: ourenergy.com)

\section{Corporate Ventures and Investments}

The research and developmental efforts of ExxonMobil can rightly be reckoned here to realize its exact potential as it continues to fund and conduct research on advanced biofuels. Their present work is part of their varied multiple investments in new technologies aligned in the line of transformative potential to increase energy supplies, reduce emissions and improve operational efficiencies. In this direction, an advanced biofuels and algae research has been initiated and targeted for achieving the technical capability to produce 10,000 barrels per day by 2025 is a matter to understand the potential of algal biofuel for the future to come. There are many houses worldwide working in this direction (Fig.4).

ExxonMobil in collaboration with Synthetic Genomics reported a breakthrough in 2017 into advanced biofuels research in doubling its lipid content from 20 per cent to $40-55$ per cent in a genetically engineered strain of Nannochloropsis gaditana derived from its natural strains and its further commercial applications. Other corporate sectors like Solazyme, Sapphire Energy and Algenol etc. started commercial sale of algal biofuel from 2012, 2013 and 2015 respectively. SuSeWi has already embarked on a visionary project having the operational pilot plant in Morocco aiming for creating a global largest algae farm for producing the valuable protein and long chain omega-3s for the aquafeed sector.

\section{Ethical aspects in technology adoption}

As the human society is facing a challenge to search for appropriate energy solutions, it is more of an ethical issue rather than that of a technical feasibility due to the already existed too much of stresses on earth's resilience as there is an anthropocentric impact on global life systems. Consequently, we have to answer ourselves several questions that (i) 
how best the algal biofuels fit into the bioenergy checklists to face the overall energy demand and supply scenario in balancing the ethical and moral dimensions alongside scientific, technical and economic analysis, (ii) whether adoption of this technology will inculcate any imbalance in energy consumption between developed and developing economy looking into the canvas of energy equity. As we are aware that every energy technology has its own strengths and weaknesses, so it is pertinent to have an indepth analysis with respect to human values and values attributed to natural resources. It will help us to realize early about the precautionary principles associated with natural resources utilization and people's perceptions and choices as a critical parameter for regulating the acceptability and adaptability of a particular technology and in this case it is on algal biofuels.

\section{Global and Regional Policies}

Various global and regional policies are evolving continuously and in place which will help us not only to achieve the United Nation's (UN) Sustainable Development Goal (SDG) and Millennium Development Goals (MDG) but also the India's National Policy on Biofuel (NPB)-2018 wherein there is a clear reflection in the clause 1.4 of preamble of NPB "Biofuels can increasingly satisfy these energy needs in an environmentally benign and cost effective manner while reducing dependence on import of fossil fuels and thereby providing a higher degree of National Energy Security" and also in its clause 3.4 of Definitions and Scope reflects "the scope of the policy encompasses bioethanol, bio-diesel and other biofuels, and 'bio-ethanol' as: ethanol produced from biomass such as sugar containing materials, like sugar cane, sugar beet, sweet sorghum, etc.; starch containing materials such as corn, cassava, algae etc.; and, cellulosic materials such as bagasse, wood waste, agricultural and forestry residues etc.

However, with optimism, we can envisage that algal food and fuel coproduction can mitigate greenhouse gas emissions while improving land and water-use efficiency, although there lies a conflict in ensuring energy, water, food, and climate security simultaneously. It is also the fact that generally algae are being pursued as a feedstock for both food and fuels due to algae's ability to grow on non-arable land.

It is very important to improve our understanding on operations on algal biofuels and associated other products by integrating biology, ecology and engineering at greater magnitude. In this context, the integrating biological aspects comprises of studying the individual and community of strains and its capability, cultivating these strains with optimum growth and stability, understanding metabolic pathways of lipid, carbon capture potential, its maintenance and also the contamination factors and agents associated with.

In resource supply, and integrating energy, extraction and conversion of lipid to bioproducts and fuels, waste processing and possible recycling, cost analysis cum sustainable assessment will be carried out by the application of engineering. Enriching the algal biofuel productions with nano-additives is coming up as a newer cutting-edge technological dimension in this context. Numerous nano-additives such as nano-fibres, nano-particles, nano-tubes, nanosheets, nanodroplets, and other nano-structures' applications have been in place to facilitate algae growth to biofuel utilization. Prospects of solid nano-additives and nano-fluid applications in the better future on algae production, algal biomass conversion to biofuels as well as enhancement of biofuel 
combustion for revolutionary advancement in biofuel technology. As nowadays, the biofuel has come to the spotlight worldwide as an alternative fuel due to its capacity to adapt with gasoline for a maximum of 85 per cent blending as researchers pointed out without compromising with engine modifications, the potential of algae as a biofuel is gearing up worldwide and got its righteous position in the Indian national biofuel policy. Looking into the huge areas of both hot and cold desert landscape of India and its potential as it has already been proved elsewhere globally to be very efficiently feasible, there should be some clauses need to be embedded within national policy specific to this regions in terms of algal farming as biorefinery by pondering upon following points.

Algae can easily be grown in desert regions having plenty of sunshine and access to unusable water.

Provides an opportunity to cultivate on large land masses having no negative bearing on ecosystem.

There is a necessity for the use of photobioreactors to negate the high rates of evaporation from open air race ways.

Globally there are so many programs focused on developing the algal farm in desert regions utilizing shallow saltwater pools.

Worldwide, many leading companies are in their mission to cultivate algae in desert both for fuel and non-fuel purposes i.e; as a biorefinery.

These can easily be experimented in a pilot scale for its future commercialization to strengthen the biofuel production scenario of the country and thereby will comply upon with the targeted national commitments for the sustainable developmental goals (SDGs) of the United Nations.

\section{Acknowledgement}

The authors extremely grateful and thankful to Dr. O. P. Yadav, Director, ICAR-CAZRI for his continuous support in coming up with ideas which can possibly be perceived and harvested for its research and developmental applications in the desert landscape (both hot and cold arid ecosystem) of the country for alternative bio-resources utilization to ensure energy security through green energy harvesting as a part of sustainable natural resources utilization and environmental management. Authors are greatly indebted to Dr. S. Ayyappan, Ex-Director General and Secretary, DARE for his leading role in the country in microalgal applications as feed and energy with whom one of the authors was associated for long during the beginning years which has motivated this team to synthesize this information.

\section{References}

Aach, H. G. (1952). "Über Wachstum und Zusammensetzung von Chlorella pyrenoidosa bei unterschiedlichen Lichtstärken und Nitratmengen". Archiv für Mikrobiologie. 17: 213-246.

Acharya, Somen, Singh, Narendra, Katiyar, Anand S. K., Maurya, B. and Srivastava R.B. () Improving soil health status of cold desert Ladakh region. DIHAR, DRDO, ClO56 APO, Leh: Extension Bulletin No.24

Allen, J., Unlu, S., Demirel, Y., Black, P., and Riekhof. W. (2018). Integration of biology, ecology and engineering for sustainable algal- based biofuel and bioproduct biorefinery. Bioresour. Bioprocess. (2018) 5:47. https://doi.org/10.1186/s40643-0180233-5

Ayyappan, S. Pandey, B.K. Sarkar, S. Saha, Dipankar. and Tripathi, S.D. 1991. Potential of Spirulina as a Feed Supplement for Carp Fry. Proc. Nat. Symp. Freshwat. Aqua. (Central Institute of Freshwater Aquaculture of Indian Council of Agricultural Research), pp $86-88$. 
Bahadar A, Bilal Khan M (2013) Progress in energy from microalgae: a review. Renew Sustain Energy Rev 27:128-148. https ://doi.org/10.1016/j.rser.2013.06.029

Behera U.K. and France, J. (2016). Arid Zones. Advances in Agronomy

Bhatnagar A, Bhatnagar M, Chinnasamy S, Das KC (2010) Chlorella minutissima-a promising fuel alga for cultivation in municipal wastewaters. Appl Biochem Biotechnol 161:523-536. https ://doi.org/10.1007/s12010-009-8771-0

Chevuturi, A., Dimri, A. P. and Thayyen, R. J. (2018) Climate change over Leh (Ladakh), India. Theoretical and Applied Climatology: 131 (12)-pp. 531-545.

Chew KW, Yap JY, Show PL, et al. (2017). Microalgae biorefinery: High value products perspectives. Bioresour. Technol. 229:5362.

Desert

Climate. https://en.wikipedia.org/wiki/Desert_climate

Ercin AE, Aldaya MM, Hoekstra AY. (2012). The water footprint of soy milk and soy burger and equivalent animal products. Ecol. Indic. 18: 392-402.

González-Delgado ÁD, Kafarov V. (2011). Microalgae based bio-refinery: Issues to consider. C.T.F Cienc. Tecnol. Futuro. 4:522.

Hannon M, Gimpel J, Tran M, Rasala B, Mayfield S. (2010). Biofuels from algae: Challenges and potential. Biofuels. 1: 763-784.

Harder, R.; von Witsch, H. (1942). "Bericht über versuche zur fettsynthese mittels autotropher microorganismen". Forschungsdienst Sonderheft. 16: 270-275.

Harder, R.; von Witsch, H. (1942). "Die massenkultur von diatomeen". Berichte der
Deutschen Botanischen Gesellschaft. 60: 146-152.

Hariskos I, Posten C. (2014). Biorefinery of microalgae - Opportunities and constraints for different production scenarios. Biotechnol. J. 9: 739-752.

Lau PS, Tam NFY, Wong YS (1995) Effect of algal density on nutrient removal from primary settled wastewater. Environ Pollut 89:59-66. https ://doi. org/10.1016/02697491(94)00044 -E

Pienkos PT, Darzins A (2009) The promise and challenges of microalgal derived biofuels. Biofuels Bioprod Biorefining 3:431-440. https ://doi. org/10.1002/bbb.159

Priyadarshani I, Rath B. (2012). Commercial and industrial applications of micro algae $-\mathrm{A}$ review. J. Algal Biomass Utln. 3: 89-100.

Razon LF, Tan RR (2011) Net energy analysis of the production of biodiesel and biogas from the microalgae: Haematococcus pluvialis and nannochloropsis. Appl Energy 88:35073514. https ://doi.org/10.1016/j.apene rgy.2010.12.052

Reddy, Mallikarjun () Climate of Arid Zone in India.

http://www.biologydiscussion.com/ecology/ arid-zone/climate-of-arid-zone-inindia/34423

Roberts GW, Fortier MOP, Sturm BSM, StaggWilliams SM (2013) Promising pathway for algal biofuels through wastewater cultivation and hydrothermal conversion. Energy Fuels 27:857-867. https ://doi.org/10.1021/ef302 0603

Shah, Sneha (2012) Can Ladakh the Cold Desert become India's Solar Desterec-Massive Benefits. Green World Investor: 2 Jan, 2012.

\section{How to cite this article:}

Dipankar Saha, M. S. Raghuvanshi and Anurag Saxena. 2020. Algae as a biorefinery: generic applicable resonance of bio-ecological engineering in exploring possibilities for desert landscape. Int.J.Curr.Microbiol.App.Sci. 9(03): 3201-3212.

doi: https://doi.org/10.20546/ijcmas.2020.903.367 